\title{
INTERNATIONAL MIGRANT WORKERS IN TOURISM AND HOSPITALITY INDUSTRY, LANGKAWI, MALAYSIA: DOES THEIR DEMOGRAPHIC PROFILE MATTER?
}

\author{
Nurhazani MOHD SHARIFF* \\ School of Tourism, Hospitality \& Event Management, COLGIS, University \\ Utara Malaysia 06010, Sintok, Kedah, Malaysia, e-mail: hazani@uum.edu.my \\ Azlan ZAINOL ABIDIN \\ School of Languages, Civilization \& Philosophy, CAS, University \\ Utara Malaysia 06010, Sintok, Kedah, Malaysia, e-mail: azlan@uum.edu.my \\ Azmil Munif MOHD BUKHARI \\ Langkawi Development Authority \\ o70oo, Langkawi, Kedah, Malaysia, e-mail: azmil@lada.gov.my
}

\begin{abstract}
Citation: Mohd Shariff, N., Zainol Abidin, A., Mohd Bukhari, A.M. (2019). INTERNATIONAL MIGRANT WORKERS IN TOURISM AND HOSPITALITY INDUSTRY, LANGKAWI, MALAYSIA: DOES THEIR DEMOGRAPHIC PROFILE MATTER? GeoJournal of Tourism and Geosites, 25(2), 349-357. https://doi.org/10.30892/gtg.25206-364
\end{abstract}

\begin{abstract}
The main purpose of the study was to investigate the demographic profile of the employment of international migrant workers in the Langkawi tourism and hospitality industry. A total of 258 international migrant workers had participated in the study and the findings indicated that majority of them were male, with age ranged between 18 - 30 years old and were still single. Additionally, the findings also highlighted that the majority of the international migrant workers in Langkawi were semi-skilled and had the ability to speak good English. Most of them had migrated from Indonesia and had been working in the accommodation sector which was more towards customer service sectors. They also earned an income between RM1,00o RM4,999 a month. The findings of the study would significantly assist the Workforce Department in designing and preparing a comprehensive policy regarding the employment of international migrant workers in Langkawi.
\end{abstract}

Key words: International migrant workers, Langkawi, tourism and hospitality industry, demographic profile

\section{INTRODUCTION}

Tourism and hospitality employment has a significant economic and social impact on a destination thus human resource analysis is considered an important component of

\footnotetext{
* Corresponding author
} 
tourism and hospitality research. At the same time, immigration for tourism has caused a demand for employment (Merrill, 1982). It is further believed that the creation of employment opportunities can bring migration into the tourism and hospitality industry (Connell, 1987:108). Some researchers have found that migration is common in tourism employment, especially where the seasonality of the tourist traffic is significant (Monk \& Alexander 1986; Lever, 1987). According to Halseth (1999), tourism development also brings employment opportunities to a destination area thus it can be extremely attractive for destination areas seeking economic development alternatives, especially during a period of economic transition. However, the tourism and hospitality industry is expected to have a difficult time attracting and keeping labor.

Further, the tourism industry is also considered unpopular as an employment choice because of its low status and large surplus of unskilled labor market (Saunders, 1981). While estimates of the number of jobs in tourism and hospitality continue to grow, there is also a concern that the industry will experience a labor shortage in the near future (CTHRC, 2003). In fact, the industry largely has an image of providing low skilled and low payed jobs, and attributes that are not likely to motivate mobility into the industry (Krakover, 2000; Hjalager \& Andersen, 2001).

These issues were solved by recruiting international migrant workers to work within the tourism and hospitality industry. The study is conducted to investigate the international migrant workers demographic profile who worked in the tourism and hospitality industry in Langkawi, Malaysia (Figure 1).

The development of Langkawi as tourist destination has begun with the conferring on the Duty Free Zone status in 1987, followed by the establishment of the Langkawi Development Authority (LADA) in 1990 and has been one of the agendas in the Sixth Malaysia Plan (1991 - 1995). The growth in tourist arrivals to Langkawi has spurred a corresponding increase in the demand within the tourism service industry itself. The number has significantly increased in 2004 when it reached 2.2 million tourist arrivals out of the 15.7 million received for Malaysia.

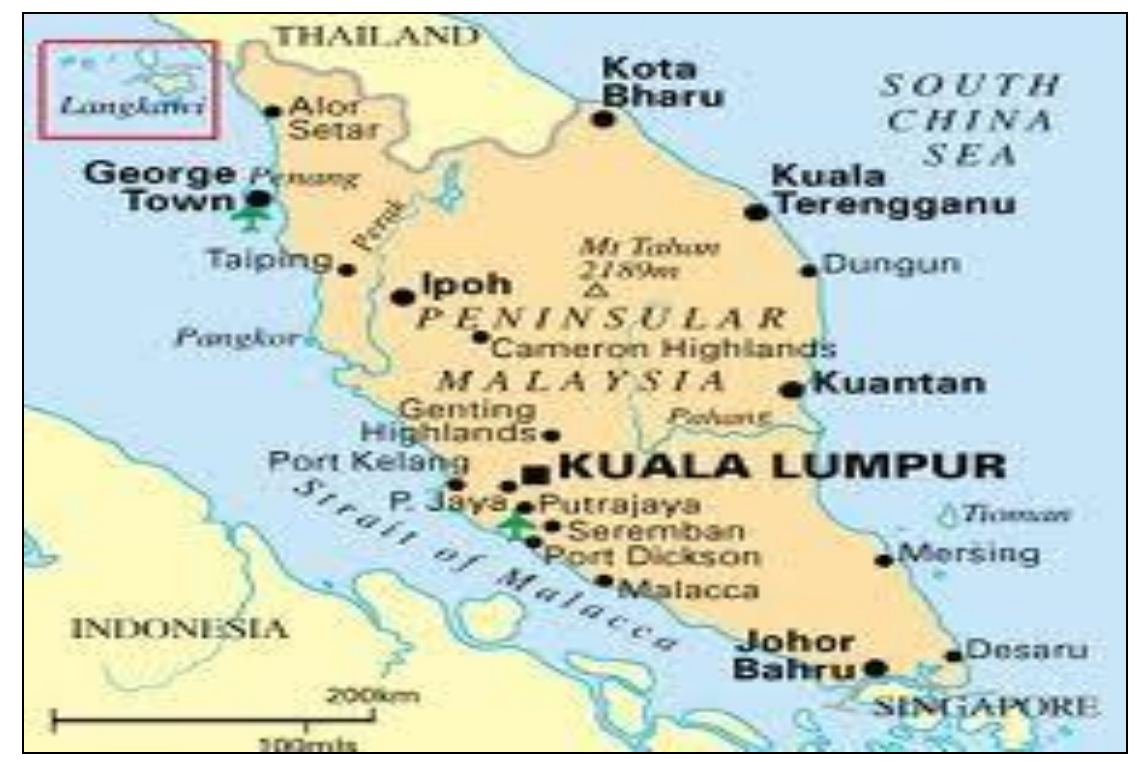

Figure 1. Location of Langkawi, Malaysia

(Source: Google maps) 
In 2012, Langkawi has received about RM 2.6 billion revenue from the approximately 3 million recorded tourist arrivals (Langkawi Development Authority, 2016). The government has taken prompt action from these statistics by proposing a Blueprint Langkawi by the year 2015 to make Langkawi Island listed as 10 highest island visited by tourists as well as to make Langkawi as a luxury tourist destination. Added to this, the target in economics is to double tourism in Langkawi Gross National Income (GNI) of RM 0.8 billion in 2010 to RM 1.9 billion in 2015. Further, recipients are also expected to double from RM 1.9 billion tourists in 2010 to RM 3.8 billion in 2015 through the launching of marketing campaign based on customer needs. The tremendous growth of tourism in Langkawi has led to greater employment of international migrant workers. It is important therefore to understand their demographic profile as to design and plan a proper and effective recruitment strategy.

\section{LITERATURE REVIEW}

According to Bell et al., (2002), migration is usually described spatially as action across the border of an area unit. Additionally, migration of international worker is believed can help to fill labor shortages in high-skills and also low-skill parts of the market (IOM, 2010). Based on a report from the World Tourism Organization (WTO, 1995), the tourism industry employs in excess $11,194,418$ people worldwide and represents approximately 5 per cent of the world's total travel and tourism workforce.

Lee-Ross and Pryce (2010) have noted that the presence in large numbers of migrant workers in such hospitality organizations is of consequence for tourism academics as it carries implications for both destination image and the tourist experience of the destination. Although many studies have suggested positive outcomes from employing foreign workers, some negative consequences for the industry have also been identified. Choi et al., (2000) and William and Hall (2000) have argued that this ongoing relationship between migration, migrant labor and tourism employment continues partly because a mobile international workforce offers a solution to labor shortages where the local workforce is not willing to be engaged in low pay, low status and seasonal employment. Harrison (1992) on the other hands has supported the view with an example from Kenya, where despite the high numbers of new jobs created by tourism, regional unemployment remained high because of the large numbers of migrants who sought work within the tourism sector.

Another question regarding migration which should be addressed is whether migrants compete for tourism jobs with the local labor force or whether they fill a niche left open for social, cultural, economic or political reasons. Furthermore, the employment of international workers in tourism and related service sectors presents a series of opportunities alongside challenges for migrants, employers and host communities. Several studies have been conducted on investigating demographic profile. The characteristics of tourism employment have been found varied among destinations for instance occupation, skills and gender (Monterrubio \& Espinosa, 2013). The employment were dominated by men compared to women and the reason was probably caused by the cultural structure of local communities. A recent study by Erden and Yolal (2016) have found that demographic variables also contributed as factors determining residents' perceptions of international fair in Izmir. They also noted that residents' perceptions vary across their age groups, occupation and educational level.

Chi et al., (2009) for instance have studied the relation between perceived image of destination and tourists' demographic factors such as gender, age, education, occupation, income and marital status. The study have indicated that gender and 
education determined tourists' perceptions on destination image. Previously, Beerli and Martin (2003) have investigated the relation between image components and tourists' socio-demographic characteristics as a meaningful factor in terms of social class, education, age and gender. However, study on international migrant workers demographic profile has not aggressively been conducted.

\section{METHODOLOGY}

The study applied a purposive sampling technique where the selected respondents consisted of the international migrant workers who legally entered Langkawi to work in the tourism and hospitality industry. The selected technique eventually enabled researches to obtain questionnaires quickly and economically (Sekaran \& Bougie, 2010; Zikmund et al., 2010). Since there is no exact number of the international migrant workers working in the service sector specifically in Langkawi, the number of population was determined according to the general number of international migrant workers working in the service sector in Malaysia as stated by the Department of Statistic Malaysia (2012). There was a number of 291,997.44 international migrant workers working in the service sector and using a table of sample size provided by Krejcie and Morgan (1970), 384 respondents were selected to represent the sample.

Since the purpose of the study was to develop a profile of international migrant workers working in the tourism and hospitality sector, a self-administered survey questionnaire was used as research instrument. According to Sekaran and Bougie (2010), survey questionnaire is an efficient data collection mechanism to ensure relevancy and consistency of information gathered as the responses are objective, standardised and comparable. To achieve this objective, only 4 and 5 star hotels, fast food service restaurants and international cuisine restaurants in Pantai Cenang area, Langkawi were involved. This was due to the fact that these sectors recuited legal international workers. Pantai Cenang was selected as there are many tourism and hospitality sectors at the location. Additionally, Pantai Cenang also represents major tourism spots and activities in Langkawi. Hence, the study had distributed a total number of 400 questionnaires to the hotels. The human resource managers or related officers at the sectors were contacted through phone calls before asking their participation in the study.

Appointment date for meeting was set and the questionnaires were handed in to the human resource managers or related officers during the meeting. They were asked to distribute the questionnaires to their international migrant workers. Within 2 weeks, the researcher approached the human resource managers or related officers to collect the completed questionnaires. On the other hand, the secondary data in the study was assessed and analysed using all other sources such as literature search and reports from various sources. Literature review also covered relevant online journal articles through online databases and also reports from newspapers and published statistics.

\section{FINDINGS}

A total of 258 useable questionnaires out of 400 were obtained, representing $64.5 \%$ response rate. Table 1 depicts the findings of the survey. It is indicated that the majority of international migrant workers are male (70.5\%) whilst the remaining are female (29.5\%). As for the age distribution, the findings show that the majority of them are between 18 to 30 years old (69.4\%), followed by the category of age between 31 to 50 years old (27.1\%), then by those who are below 18 years old $(2.7 \%)$ and the remaining are above 50 years old (o.8\%). The findings also highlight that most respondents are still single (51.9\%). Meanwhile some of them are married (40.3\%), followed by a small 
number of them who are divorced (4.3\%) and others are under other category (3.5\%). The respondents were further asked to state their country of origin. The findings of the survey indicate that the highest percentage of international migrant workers are from Indonesia (21.3\%). The findings then reveal most of them are from other countries such as Nepal, United Kingdom and few are from Maldives (20.9\%).

Further, the findings show that some of the international migrant workers are from India (17.8\%), then followed by Bangladesh (15.9\%), Philippines (12.4\%), Thailand (8.5\%), Pakistan (2.7\%) and only few are from Vietnam (0.4\%).

More, the findings emphasize that the majority of international migrant workers have secondary school education (41.4\%), followed by high school (38.4\%), college (13.6\%) and university (7.0\%). Additionally, the majority of them have possessed a certificate (50.8\%). In fact, most of them have also possessed diploma/higher diploma (43.0\%) and followed by undergraduate degree (5.0\%) and postgraduate degree (1.2\%). This question however indicated a missing data of $11.6 \%$.

Table 1. The demographic profile of international migrant workers

\begin{tabular}{|c|c|c|}
\hline Items & Number & Percentage \\
\hline $\begin{array}{c}\text { Gender: } \\
\text { Male } \\
\text { Female }\end{array}$ & $\begin{array}{c}182 \\
76 \\
\end{array}$ & $\begin{array}{r}70.5 \\
29.5 \\
\end{array}$ \\
\hline $\begin{array}{l}\text { Age: } \\
\text { Below } 18 \text { years old } \\
18-30 \text { years old } \\
31-50 \text { years old } \\
\quad \text { Above } 50 \text { years old } \\
\end{array}$ & $\begin{array}{c}7 \\
179 \\
70 \\
2 \\
\end{array}$ & $\begin{array}{c}2.7 \\
69.4 \\
27.1 \\
0.8 \\
\end{array}$ \\
\hline $\begin{array}{l}\text { Marital status: } \\
\text { Single } \\
\text { Married } \\
\text { Divorced } \\
\text { Others }\end{array}$ & $\begin{array}{c}134 \\
104 \\
11 \\
9\end{array}$ & $\begin{array}{c}51.9 \\
40.3 \\
4.3 \\
3.5\end{array}$ \\
\hline $\begin{array}{l}\text { Country of origin: } \\
\text { Bangladesh } \\
\text { Philippines } \\
\text { Indonesia } \\
\text { India } \\
\text { Pakistan } \\
\text { Thailand } \\
\text { Vietnam } \\
\text { Others }\end{array}$ & $\begin{array}{c}41 \\
32 \\
55 \\
46 \\
7 \\
22 \\
1 \\
54\end{array}$ & $\begin{array}{c}15.9 \\
12.4 \\
21.3 \\
17.8 \\
2.7 \\
8.5 \\
.4 \\
20.9\end{array}$ \\
\hline $\begin{array}{l}\text { Educational level: } \\
\text { Secondary school } \\
\text { High school } \\
\text { College } \\
\text { University } \\
\end{array}$ & $\begin{array}{c}106 \\
99 \\
35 \\
18 \\
\end{array}$ & $\begin{array}{c}41.1 \\
38.4 \\
13.6 \\
7.0\end{array}$ \\
\hline $\begin{array}{l}\text { Qualification: } \\
\text { Certificate } \\
\text { Diploma/higher diploma } \\
\text { Undergraduate degree } \\
\text { Postgraduate degree }\end{array}$ & $\begin{array}{c}131 \\
111 \\
13 \\
3\end{array}$ & $\begin{array}{c}50.8 \\
43.0 \\
5.0 \\
1.2\end{array}$ \\
\hline
\end{tabular}




\begin{tabular}{|l|c|c|}
\hline Skills level: & & \\
Unskilled & 87 & 33.7 \\
Semi-skilled & 171 & 66.3 \\
\hline Proficiency in English: & 44 & \\
Very little & 63 & 17.1 \\
Little & 93 & 24.4 \\
Good & 58 & 36.0 \\
Very good & & 22.5 \\
\hline Job in sector: & 106 & \\
Accommodation & 3 & 41.1 \\
Transportation & 84 & 1.2 \\
Food and beverages & 27 & 32.6 \\
Visitor attractions & 38 & 10.5 \\
Others & & 14.7 \\
\hline Job position: & 16 & \\
Administration & 195 & 6.2 \\
Customer service & 15 & 75.6 \\
Security service & 32 & 12.4 \\
Others & & \\
\hline Number of years working in & 63 & 24.4 \\
the sector: & 159 & 61.6 \\
Less than 1 year & 31 & 12.0 \\
1 - 5 years & 5 & 1.9 \\
6- 10 years & & \\
More than 10 years & 215 & 15.5 \\
\hline Income per month: & 2 & 0.8 \\
Less than RM1,0oo & 1 & 0.4 \\
RM1,0oo - RM4,999 & & \\
RM5,ooo - RM9,999 & & \\
More than RM10,000 & & \\
\hline
\end{tabular}

As for the skills level, the findings show that the majority of them are semiskilled workers (66.3\%) whilst the rest is unskilled (33.7\%). The majority of them also have the ability to speak good English (36.0\%) and very good English (22.5\%). The remaining on the other hand has low ability to speak English (24.4\%) and very low ability to speak English (17.1\%). Further, it is noted that most of them are working in the accommodation sector (41.1\%), the food and beverages sector (32.6\%), other tourism and hospitality related sectors (14.7\%), the visitor attractions sector (10.5\%) and the transportation sector (1.2\%). As for their position in the sector, majority of them are involved in the customer service sector (75.6\%). It is then followed by other positions (12.4\%), administration (6.2\%) and only few in the security service (5.8\%).

The findings also highlight that the majority of the respondents have been working in the industry between $1-5$ years (61.6\%). This is followed by less than 1 year (24.4\%), between $6-10$ years (12.0\%) and the remaining has been working for more than 10 years (1.9\%). Additionally, most of the international migrant workers have an income between RM1,000 - RM4,999 per month (83.3\%). Few of them have an income less than RM1,000 (15.5\%), some have an income between RM5,000 - RM9,999 per month (o.8\%) and the remaining have more than RM10,000 income per month.

The respondents were also asked to indicate reasons for working in the tourism and hospitality sector and also reasons for choosing Langkawi as a destination to migrate. The findings (Table 2) highlight that the main reason for them to work in the tourism and 
hospitality industry is 'to gain new experience' $(52.3 \%)$. This is then followed by 'follow their friends' (41.1\%), 'high wages' (37.2\%), 'love meeting with people' (28.3\%), 'easy to get job' (22.1\%), 'job promotion' (7.8\%) and 'family concerns' (7.4\%) and finally few stated as 'other reasons' for choosing the industry (5.4\%). As for the questions regarding reasons for choosing Langkawi, the findings emphasize that the main reason is because of the 'beautiful island' (50.8\%). The respondents also stated the reason as 'easy place to get around' (32.9\%), followed by 'a peaceful place' (32.2\%), 'friendly people' (31.4\%) 'due to company concerns' (24.0\%), 'family concerns' (12.0\%) and 'other related reasons' (7.4\%).

Table 2. The reasons for choosing the industry and Langkawi

\begin{tabular}{|l|c|c|}
\hline \multicolumn{1}{|c|}{ Items } & Number & Percentage \\
\hline $\begin{array}{l}\text { Reasons for choosing the } \\
\text { industry: }\end{array}$ & & \\
To gain new experience & 135 & 52.3 \\
Following friends & 106 & 41.1 \\
High wages & 96 & 37.2 \\
Love meeting with people & 73 & 28.3 \\
Easy to get job & 57 & 22.1 \\
Job promotion & 20 & 7.8 \\
Family concerns & 19 & 7.4 \\
Other reasons & 14 & 5.4 \\
\hline Reasons for choosing & & \\
Langkawi: & & \\
Beautiful island & 131 & 50.8 \\
Easy to get around & 85 & 32.9 \\
Peaceful place & 83 & 32.2 \\
Friendly people & 81 & 31.4 \\
Company concerns & 62 & 24.0 \\
Family concerns & 31 & 12.0 \\
Other reasons & 19 & 7.4 \\
\hline
\end{tabular}

\section{DISCUSSION}

It can be concluded that the majority of the international migrant workers in Langkawi is male. Most of them are also in the category of 18 - 30 years old. Additionally most of them are still single. The international migrant workers in Langkawi are also from Indonesia and majority is secondary school leavers with certificate. They are also acknowledged as semi-skilled workers and can speak good English. The findings also indicate that the majority of the international migrant workers in Langkawi are working in the accommodation sector, hence it is a fact that the majority of them are working in the customer service area. Most of them have been working in Langkawi for almost 1 - 5 years with RM1,00o - RM4,999 income per month. Looking at this scenario, it can be highlighted that the international migrant workers in Langkawi are semi-skilled labors with good qualification which are in line with their positions to serve customers from all over the world.

The profile of international migrant workers working in the tourism and hospitality industry within Langkawi provides significant data and information to various stakeholders who really want to understand the scenario of employing foreign workers. The profile is vital and significant as it may assist the human resource manager particularly in the hotel sectors to deal with the issue of labor shortages among 
the local people. This phenomenon is important particularly in the tourism and hospitality industry within Langkawi. It can be assumed that the issue of labor shortages in the industry can be solved by having recruited international migrant workers as they may perceive the wages offered by the industry as high compared to the local people. Another reason could also be due to the fact that the currency exchange in their countries is high such as for Indonesia and Thailand.

Additionally, the trend of having recruited Indonesian workers may provide more benefits to Langkawi since they share similar culture and values. Hence, they do not have to be trained in these aspects when dealing with customers. In fact, it cannot be argued that the Indonesian can speak better English compared to international workers from Thailand and Bangladesh. However, several negative impacts eventually might need to be considered for instance the discrimination of local workers labors, crime, misuse of languages and others. Further, the findings from the survey also indicated that majority of the international migrant workers are working in the industry to gain new experience, besides following their friends and also due to the high wages offer by the tourism and hospitality industry today. Since Langkawi is a world tourist destination with various hospitality sectors catering to fulfill the needs of international tourists, most of the sectors offer high salary to compete with their competitors. Additionally, majority of the international workers have chosen to migrate to Langkawi due to the fact of the island itself which they consider as a beautiful island and easy to get around. More, they also feel that Langkawi is a peaceful tourist destination and surrounding by friendly people which make them confortable and safe to be around for a long period of time.

\section{CONCLUSION}

This study has involved only the international migrant workers who were legally working in the tourism and hospitality sectors in Langkawi. More, the study has focused on Langkawi since it is a world known tourist destination composed of various hospitality sectors and eventually consisted of many international migrant workers. It did not represent Malaysia as a whole. Subsequently, the findings may only present the majority of international migrant workers who have been working at the lower managerial level including skilled and semi-skilled workers and excluding the expatriates. It is suggested that for future research, the international migrant workers would include all categories of workers in the tourism and hospitality sectors in Langkawi. Furthermore, another study should also be conducted to investigate the factors influencing the international migrant workers to work within the tourism industry in Langkawi.

\section{Acknowledgements}

This study is sponsored by the Ministry of Higher Education, Malaysia under the Fundamental Research Grant Scheme (FRGS) S/O Code 13029.

\section{REFERENCES}

Bell, M., Blake, M., Boyle, P., Rees, P., Stillwell, J., \& Hugo, G. (2002). Cross-national comparison of internal migration : issues and measures. Journal of the Royal Statistical Society. Series A (Statistics in Society), 165(3), 435-464. Retrieved from http://www.jstor.org/stable/3559697.

Beerli, A., \& Martin, J.D. (2003). Tourists' characteristics and the perceived image of tourist destinations: a quantitative analysis - a case study of Lanzarote, Spain. Tourism Management, 25, 623-6. 
Choi, J. G., Woods, R. H., \& Murrmann, S. K. (2000). International labor markets and the migration of labor forces as an alternative solution for labor shortages in the hospitality industry. International Journal of Contemporary Hospitality Management, 12(1), 61-67.

Chi Christina, G.Q, Gursoy, D., \& Qu, H. (2009). Demographic variables and loyalty formation: a systematic examination. Paper presented at the Hospitality \& Tourism Management International CHRIE Conference Refereed Track. University of Massachusetts, Amherst, Retrieved from: http://scholarworks.umass.edu/

Connell, J. (1987). Migration, rural development and policy formation in the South Pacific. Journal of Rural Studies, 3(2), 105-121.

Erden, Ömer İlke \& Yolal, M. (2016). Residents' socio-economic perceptions of an international fair. GeoJournal of Tourism and Geocities, 2(18), 152-161.

Halseth, G. (1999). We came for the work: situating employment migration in B.C.'s small, resource-based, communities. The Canadian Geographer, 43(4), 363-81.

Harrison, D. (1992). International tourism and the less developed countries: The background. In Harrison, D. (ed.) Tourism and the Less Developed Countries. London: Belhaven Press.

Hjalager, A., \& Andersen, S. (2001). Tourism employment: Contingent work or professional career? Employee Relations, 23(2), 115-129.

Krakover, S. (2000). Partitioning seasonal employment in the hospitality industry. Tourism Management, 21, 461-471.

Krejcie, R. V., \& Morgan, D. W. (1970). Determining sample size for research activities. Educational and Psychological Measurement, 30, 607-610.

Lee-Ross, D., \& Pryce, J. (2010), Human resources and tourism. Skills, culture and industry. Bristol: Channel View Publications.

Lever, A. (1987). Spanish tourism migrants. The case of Lloret de Mar. Annals of Tourism Research, 14(4), 449-470.

Merrill, W. D. (1982). Tourism employment and migration. In Rajotte, F. The impact of tourism in the Pacific (ed.). 28-42. Peterborough: Environmental and Resource Studies Programme.

Monk, J., \& Alexander, C. (1986). Free port fallout: gender, employment, and migration on Margarita Island. Annals of Tourism Research, 13, 393-413.

Monterrubio, J. C. \& Espinosa, B. (2013). Characterisation of ecotourism employment in a developing world destination. GeoJournal Tourism and Geocities, 1(11), 54-65.

Saunders, K. C. (1981). Social Stigma of Occupations. Farnborough: Gower.

Sekaran, U., \& Bougie, R. (2010). Research method for business: A skill building approach (5 ${ }^{\text {th }}$ ed.). West Sussex, UK: John Wiley \& Sons Ltd.

Williams, A., \& Hall, C.M. (2000). Tourism and migration: new relationships between production and consumption. Tourism Geographies, 2(1), 5-27.

Zikmund, W. G., Banin, B. J., Carr, J. C., \& Griffin, M. (2010). Business research methods (8 ${ }^{\text {th }}$ ed.) USA: SouthWestern Publishing Company.

*** CTHRC. (2003). About the CTHRC, Canadian Tourism Human Resource Council. 2003.

*** Department of Statistics (2012). Retrieved from. https://www.statistics.gov.my

*** IOM (2010). International Organization for Migration, Labour migration from Indonesia: An overview of Indonesia migration to selected destinations in Asia and the Middle-East. Retrieved from http://www.iom.int/jahia/webdav/shared/shared/mainsite/published_docs/Final-LM-ReportEnglish.pdf.

*** Langkawi Development Authority (LADA). (2016). Tourist Arrival in Langkawi [Online]. http://www. lada.gov.my/Langkawi/statistic.htm.

*** Location of Langkawi, Malaysia. www.google.com.my/maps

*** World Tourism Organization - WTO (1995). Retrieved from. www.statistics.unwto.org

Submitted:

18.10.2018
Revised:

10.04.2019
Accepted and published online 19.04.2019 